\title{
A Mini Review : Clinically Significant Potential Drug-Drug Interactions In COVID-19 and Comorbid Therapy
}

\author{
Ana Khusnul Faizah*, Nani Wijayanti Dyah Nurrahman, Oki Nugraha Putra \\ Study Program of Pharmacy, Faculty of Medicine, Hang Tuah University, Surabaya, Indonesia
}

\begin{abstract}
Coronavirus disease 2019 (COVID-19) is a disease caused by severe acute respiratory syndrome coronavirus 2 (SARS-CoV-2) and can be aggravated by comorbid diseases. In administering COVID-19 therapy, we need to consider potential drug-drug interactions (pDDIs) with comorbid drugs. Most patients with comorbid diseases get polypharmacy, therefore the risk of pDDIs increases. Potential drug-drug interactions can cause unwanted effects such as toxicity to death. There is no on-label therapy for COVID-19 but FDA has Emergency Use Authorization (EUA) for hydroxychloroquine, chloroquine, azithromycin, remdesivir, ritonavir, and lopinavir. Some COVID-19 treatment potential drug-drug interactions have a level of severity $\mathrm{C}$ and $\mathrm{D}$, so there is a high need for close monitoring during drug administration or modification therapy.
\end{abstract}

Keywords: COVID-19; hydroxychloroquine; remdesivir; azithromycin; pDDIs; lopinavir

*corresponding author

Email: ana.faizah@hangtuah.ac.id

\section{INTRODUCTION}

Corona Virus Disease-2019 (COVID-19) is a new disease caused by the coronavirus attacking the respiratory tract and was first reported in Wuhan, China on December 31, 2019. On January 30, 2020, the Public Health Emergency of International Concern announced that it was an international pandemic (World Health Organization, 2020). Not much clinical data and management therapy is known considering this is a new disease. There is no on-label therapy and vaccine for COVID-19. The number of COVID-19 patients is increasing from day to day throughout the world (John Hopkins University, 2020).

There are asymptomatic to severe symptoms shown by patient COVID-19. Symptoms are felt 2-14 days after the patient is exposed. Symptoms reported include fever $(83-99 \%)$, cough $(59-82 \%)$, weakness $(44-70 \%)$, anorexia (40-84\%), difficulty breathing (31-40\%), phlegm (28-33\%), and myalgia (11-35\%). Based on available data, the elderly and people with comorbid diseases have a greater risk of COVID-19 (Centers for Disease Control and Prevention, 2020).

Of 216 countries, 4.7 million patients were confirmed COVID-19, and $0.4 \%$ of patients from Indonesia (Ministry of Health, Republic of Indonesia, 2020). The highest number of patients by age was among those from the age group of $15-44$ years $(55.1 \%)$ and $>65$ years (41.9\%). COVID-19 patients with high severity in the $15-49$ years old group $(41.15 \%), 50-64$ years $(31.3 \%)$, and $>65$ years $(27.0 \%$ ) (Guan et al., 2020). Case
Fatality Rate (CFR) of COVID-19 critical patients had comorbidities including cardiovascular disease $10.5 \%$, diabetes mellitus $7.3 \%$, chronic respiratory disease $6.3 \%$, hypertension $6 \%$, and oncological disease $5.6 \%$ (Wu \& McGoogan, 2020).

Until now there has been no drug approved by the FDA for COVID-19 therapy. Hydroxychloroquine and chloroquine sulfate already has an Emergency Use Authorization (EUA) from FDA so that it can be given to adult COVID-19 patients weighing more than $50 \mathrm{~kg}$ who are hospitalized (Food and Drug Administration, 2020). This drug is also currently in clinical trials for COVID-19 therapy called Solidarity Trial held by WHO (WHO, 2020). Guidelines for COVID-19 therapy based on The Indonesian Society of Respirology include chloroquine, hydroxychloroquine, azithromycin, oseltamivir, ritonavir, lopinavir, and remdesivir (Indonesian Society of Respirology, 2020).

The selection of COVID-19 therapy needs to consider the interaction of COVID-19 drugs with the treatment of comorbid diseases. The majority of patients with comorbidities get polypharmacy, thereby will increasing the risk of potential Drug-Drug Interactions (pDDIs). Therefore, this review is expected to provide information on clinically significant drug interactions to be a reference in the administration of COVID-19 therapy.

\section{DRUG INTERACTIONS}

Drugs administered with other drugs, herbs, food, drinks, or chemicals lead to drug interactions. Drug interactions 
can provide advantages by increasing the effectiveness of drugs, but also provide disadvantages such as reducing the effectiveness of drugs, side effects, and even toxicity. Drug interactions based on the mechanism are divided into pharmaceutics, pharmacokinetics, and pharmacodynamics (Baxter \& Stockley, 2010). Based on the occurrence, it is divided into actual and potential drug interactions, while based on the severity divided into minor (some references mention $\mathrm{A}$ and B), moderate (C), major (D), and contraindications (X) (Baxter \& Stockley, 2010; Lacy et al., 2010). In the minor category, drug interactions do not have clinically significant effects. The major category requires close monitoring during therapy, while the significant category is recommended for modification with other therapies. The contraindication category indicates that these drugs should not be given combination because the risk is greater than benefits (Lacy et al., 2010). The profile of pDDIs COVID-19 is shown in Table 1.

\section{CHLOROQUINE PHOSPHATE}

Chloroquine phosphate is an antimalarial that is metabolized and affecting the metabolism of other drugs used together and metabolized in the CYP2D6 and CYP3A4.

Magnesium trisilicate which is an antacid has pharmacokinetic interactions thereby reducing the absorption of chloroquine and hydroxychloroquine. The dissolution of chloroquine tablets was also delayed by magnesium trisilicate. The use of chloroquine and antacids need to be given in 2-4 hours (Centers for Disease Control and Prevention, 2019). Cimetidine 400 $\mathrm{mg}$ for 4 days reduces the metabolism and clearance of chloroquine $600 \mathrm{mg}$. This increases the half-life of cimetidine to 3.1-4.6 days in 10 patients. The use of this combination is recommended to be avoided and replaced with ranitidine that does not interact with chloroquine and hydroxychloroquine (Ette,1987; Baxter \& Stockley, 2010). Some chloroquine phosphate interactions that are included in category $\mathrm{C}$ are bisoprolol, digoxin, codeine, deferasirox, and tramadol. The interaction mechanism is by inhibiting metabolism and decreasing the effect of codeine and tramadol. Chloroquine is a CYP2D6 inhibitor that inhibits the metabolism of tamoxifen into an active form of metabolite. This drug interaction is included in category $\mathrm{D}$, so it needs to be considered for modification of therapy. The interaction of chloroquine with mefloquine which is also an antimalarial can increase mefloquine levels, causing the risk of prolongation of QTc and convulsions (Lacy et al., 2010).

\section{HYDROXYCHLOROQUINE}

Hydroxychloroquine in the same therapeutic class as chloroquine, so some chloroquine interactions also occur in hydroxychloroquine. There are 2 case reports related to the use of hydroxychloroquine with rifampicin. Rifampicin is an enzyme inducer, thus increasing the metabolism of hydroxychloroquine which causes increasing hydroxychloroquine clearance and the severity of lupus in both patients. Although there were only 2 case reports on this interaction, the effect was significant. In the administration of the two drugs, it is recommended to increase the dose of hydroxychloroquine and monitor closely (Harvey et al., 1995; Ahmad et al., 2012). Hydroxychloroquine decreases lysosomal insulin-insulin receptor degradation and increases insulin sensitivity. Several studies have shown improvements in fat profile and blood sugar levels. Blood sugar monitoring is still being done to prevent hypoglycemia (Seikhbahaie, 2016; Khunti, 2020; Wondafrash et al., 2020). Interacting with beta-blockers except for atenolol, cartenolol, and nadolol with moderate severity, so it is necessary to monitor blood pressure closely during therapy. Interaction with digoxin requires consideration of the selection of other drugs because it can increase digoxin levels, thereby increasing the risk of digoxin toxicity. The use of hydroxychloroquine with mefloquine is not recommended because it can increase the risk of QTc prolongation and seizures. If it must be used together, mefloquine is given 12 hours after the last dose of hydroxychloroquine (Lacy et al., 2010).

\section{AZITHROMYCIN}

Azithromycin is a macrolide class of antibiotics that is indicated for pneumonia. Azithromycin increases cardiac glycoside level, so it is not recommended to be used together (Bizjak, 1997; Gomes, 2009). In line with digoxin, QTc prolongation occurs in patients when azithromycin is used together with amiodarone. It is recommended to replace it with another drug (Samarendra et al., 2001; Baxter \& Stockley, 2010). Azithromycin can reduce the metabolism of cyclosporine and warfarin so that it is necessary to monitor during therapy. Tacrolimus level increase when used together with azithromycin, monitoring needs to be done (Mori et al., 2005).

\section{LOPINAVIR/ RITONAVIR}

Lopinavir and ritonavir are anti-HIV protease inhibitors. This class has the most pDDIs compared to other COVID-19 therapies. Close monitoring should be carried out if lopinavir/ritonavir is used together with antacids, digoxin, theophylline, tramadol, and warfarin. A female patient experienced vomiting and was taken to the emergency room after receiving ritonavir therapy for 2 days \& the patient took $0.25 \mathrm{mg}$ digoxin a day for therapy after heart surgery (Phillips et al., 2003; Hughes et al., 2007). Ritonavir is an enzyme inhibitor 
Table 1. Profile of pDDIs in COVID-19 and Its Comorbid Therapy

\begin{tabular}{|c|c|c|c|c|c|}
\hline COVID-19 Drug & Other Drug & Severity & Mechanism & Effect & Recommendation \\
\hline Chloroquine & $\begin{array}{l}\text { Antacids } \\
\text { Cimetidine } \\
\text { Bisoprolol } \\
\text { Digoxin } \\
\text { Mefloquine }\end{array}$ & $\begin{array}{l}\text { Moderate } \\
\text { Major } \\
\text { Moderate } \\
\text { Moderate } \\
\text { Contraindication }\end{array}$ & $\begin{array}{l}\text { PK } \\
\text { PK } \\
\text { PK } \\
\text { PK } \\
\text { PK }\end{array}$ & $\begin{array}{l}\text { Reduced absorption of chloroquine } \\
\text { Prolonged half-life chloroquine } \\
\text { Increased bisoprolol level } \\
\text { Increased digoxin level } \\
\text { Prologed QTc }\end{array}$ & $\begin{array}{l}4 \text { hours apart } \\
\text { Use ranitidine } \\
\text { Monitor closely } \\
\text { Monitor closely } \\
\text { Avoid combination }\end{array}$ \\
\hline Hydroxychloroquine & $\begin{array}{l}\text { Rifampicin } \\
\text { Glimepiride } \\
\text { Metformin } \\
\text { Bisoprolol } \\
\text { Digoxin } \\
\text { Mefloquine }\end{array}$ & $\begin{array}{l}\text { Major } \\
\text { Moderate } \\
\text { Moderate } \\
\text { Moderate } \\
\text { Moderate } \\
\text { Contraindication }\end{array}$ & $\begin{array}{l}\text { PK } \\
\text { PD } \\
\text { PD } \\
\text { PK } \\
\text { PK } \\
\text { PK }\end{array}$ & $\begin{array}{l}\text { Reduced hydroxychloroquine level } \\
\text { Improved glycemic control } \\
\text { Improved glycemic control } \\
\text { Increased bisoprolol level } \\
\text { Increased digoxin level } \\
\text { Prolonged QTc }\end{array}$ & $\begin{array}{l}\text { Increase dose of hydroxychloroquine \& monitor closely } \\
\text { Monitor closely } \\
\text { Monitor closely } \\
\text { Monitor closely } \\
\text { Monitor closely } \\
\text { Avoid combination }\end{array}$ \\
\hline Azithromycin & $\begin{array}{l}\text { Digoxin } \\
\text { Amiodarone } \\
\text { Warfarin } \\
\text { Tacrolimus } \\
\text { Cyclosporine }\end{array}$ & $\begin{array}{l}\text { Major } \\
\text { Contraindication } \\
\text { Moderate } \\
\text { Moderate } \\
\text { Moderate }\end{array}$ & $\begin{array}{l}\text { PK } \\
\text { PK } \\
\text { PK } \\
\text { PK } \\
\text { PK }\end{array}$ & $\begin{array}{l}\text { Increased digoxin level } \\
\text { Prolonged QTc } \\
\text { Increased warfarin level } \\
\text { Increased tacrolimus level } \\
\text { Increased cyclosporine level }\end{array}$ & $\begin{array}{l}\text { Use other class } \\
\text { Avoid combination } \\
\text { Monitor closely } \\
\text { Monitor closely } \\
\text { Monitor closely }\end{array}$ \\
\hline $\begin{array}{l}\text { Lopinavir/ } \\
\text { Ritonavir }\end{array}$ & $\begin{array}{l}\text { Digoxin } \\
\text { Theophylline } \\
\text { Warfarin } \\
\text { Nifedipine } \\
\text { Amlodipine } \\
\text { Nicardipine }\end{array}$ & $\begin{array}{l}\text { Moderate } \\
\text { Moderate } \\
\text { Moderate } \\
\text { Major } \\
\text { Major } \\
\text { Major }\end{array}$ & $\begin{array}{l}\text { PK } \\
\text { PK } \\
\text { PK } \\
\text { PK } \\
\text { PK } \\
\text { PK }\end{array}$ & $\begin{array}{l}\text { Increased digoxin level } \\
\text { Increased theophylline level } \\
\text { Increased warfarin level } \\
\text { Increased calcium channel blocker } \\
\text { (CCB) level }\end{array}$ & $\begin{array}{l}\text { Monitor closely } \\
\text { Monitor closely } \\
\text { Monitor closely } \\
\text { Use with caution }\end{array}$ \\
\hline Oseltamivir & $\begin{array}{l}\text { Statins } \\
\text { Phenytoin } \\
\text { Rifampicin } \\
\text { Amiodarone } \\
\text { Influenza vaccine } \\
\text { Probenecid }\end{array}$ & $\begin{array}{l}\text { Moderate } \\
\text { Major } \\
\text { Contraindication } \\
\text { Contraindication } \\
\text { Contraindication } \\
\text { Moderate }\end{array}$ & $\begin{array}{l}\text { PK } \\
\text { PK } \\
\text { PK } \\
\text { PK } \\
\text { PK } \\
\text { PK }\end{array}$ & $\begin{array}{l}\text { Increased creatinine kinase } \\
\text { Decreased lopinavir/ritonavir level } \\
\text { Decreased lopinavir/ritonavir level } \\
\text { Prolonged QTc } \\
\text { Decreased vaccine effect } \\
\text { Increased oseltamivir level }\end{array}$ & $\begin{array}{l}\text { Use minimal dose of statins or Pivastatin } \\
\text { Use gabapentin, lamotrigine } \\
\text { Avoid combination } \\
\text { Avoid combination } \\
2 \text { weeks after vaccine administration } \\
\text { Monitor closely }\end{array}$ \\
\hline
\end{tabular}

* $\mathrm{PK}=$ pharmacokinetic; $\mathrm{PD}=$ pharmacodynamic 
that can increase digoxin levels. Digoxin has a narrow therapeutic index so that even a little addition can reach toxic levels (Ding et al., 2004). Category D drug interactions are quite large with lopinavir/ritonavir. Drugs that interact are drugs that are routinely taken for comorbid therapy. Non-dihydropyridine Calcium Channel Blocker (CCB) levels will increase because protease inhibitors inhibit their metabolism. A 47-yearold male patient taking ritonavir/lopinavir after several years received nifedipine, furosemide, and doxazosin. The next day, the patient developed hypotension, oliguria, and generalized edema (Baeza et al., 2007). Increased levels of HMG-CoA reductase inhibitors also occur when used together with lopinavir/ritonavir, so it is recommended to modify drugs or use minimal doses and monitor the occurrence of rhabdomyolysis (Piliero, 2002; UCSF, 2019). An increase in creatinine kinase 17 times above normal is reported in 1 healthy subject out of the 20 subjects observed (Kiser et al., 2008). Protease inhibitors increase ketoconazole level so the maximum dose of ketoconazole is $200 \mathrm{mg}$ / day if given together with ritonavir. Effects phenytoin and birth control pills reduce the level of lopinavir/ritonavir. We need to be replaced with other drugs for effective therapy (Lim et al., 2004; UCSF, 2019).

The use of protease inhibitors and rifampicin is not recommended because rifampicin can reduce levels of protease inhibitors. The dose adjustment is shown a high incidence of hepatotoxicity. Vincristine and vinblastine toxicity can occur when used together with protease inhibitors, so it is recommended to replace the therapy. Protease inhibitors should not be used in conjunction with amiodarone because it can reduce amiodarone metabolism and all protease inhibitor probably have the same interaction mechanism (Baxter \& Stockley, 2010; Lacy et al., 2010).

\section{OSELTAMIVIR}

Oseltamivir is antiviral influenza that inhibits neuraminidase. Oseltamivir inhibits the replication of the influenza vaccine so that the administration of oseltamivir is recommended up to 2 weeks after influenza vaccine administration, while the influenza vaccine can be given after 48 hours of oseltamivir is stopped. Oseltamivir levels increase in patients taking probenecid together with oseltamivir. This is still safe because oseltamivir has a wide therapeutic index so that it can increase the effectiveness of oseltamivir (Baxter \& Stockley, 2010).

\section{REMDESIVIR}

There is no data on remdesivir drug interactions. This is likely due to no interactions or data related to remdesivir drug interactions. At present remdesivir has EUA from the FDA for COVID-19 therapy. This decision was made based on clinical trials that have been carried out together with NIH showing positive and significant results. Remdesivir can be given to COVID-19 pediatric and adult patients who have low oxygen levels or need a ventilator (Food and Drug Administration, 2020).

\section{CONCLUSION}

In providing effective COVID -19 therapy, drug-drug interactions should not be ignored. COVID-19 drugs have quite a lot of pDDIs through the mechanism of absorption, distribution, metabolism, and elimination. Pharmacists and the medical team that treats patients are responsible for preventing the effects of unwanted drug-drug interactions. Therefore, the quality of life of COVID-19 patients with comorbidities will improve.

\section{ACKNOWLEDGMENT}

I would like to thank Pharmacy Study Program, Hang Tuah University for technical supports on this project.

\section{REFERENCES}

Ahmad, D. F., Castello, N. A., Bielsa, M. S., Shoenenberger, A.J.A. (2012). Exacerbation of systemic autoimmune disease as a results of the onset of a tuberculosis treatment. Atencion Farmaceutica, 14(1): 56-8.

Baeza, M. T., Merino, E., Boix, V., \& Climent, E. (2007). Nifedipine-lopinavir/ritonavir severe interaction: a case report. AIDS (London, England), 21(1), 119-120. https:// doi.org/10.1097/QAD.0b013e3280117f6f.

Baxter, K., \& Stockley. (2010). Stockley's Drug Interactions. London: Pharmaceutical Press.

Bizjak, E. D., \& Mauro, V. F. (1997). Digoxinmacrolide drug interaction. The Annals of Pharmacotherapy, 31(9), 1077-1079. https://doi. org/10.1177/106002809703100918

Centers for Disease Control and Prevention. (2020, Mei 13). Corona Virus Disease 2019. Accessed Mei 21, 2020, from cdc.gov: https://www.cdc.gov/coronavirus/2019ncov/symptoms-testing/symptoms.html.

Centers for Disease Control and Prevention. (2019, Juni 24). Interaction between travel vaccines and drugs. Accessed Mei 28, 2020, from cdc.gov: https:// wwwnc.cdc.gov/travel/yellowbook/2020/preparinginternational-travelers/interactions-between-travelvaccines-and-drugs. 
Ding, R., Tayrouz, Y., Riedel, K. D., Burhenne, J., Weiss, J., Mikus, G., \& Haefeli, W. E. (2004). Substantial pharmacokinetic interaction between digoxin and ritonavir in healthy volunteers. Clinical Pharmacology and Therapeutics, 76(1), 73-84. https:// doi.org/10.1016/j.clpt.2004.02.008.

Ette, E. I., Brown-Awala, E. A., \& Essien, E. E. (1987). Effect of ranitidine on chloroquine disposition. Drug Intelligence \& Clinical Pharmacy, 21(9), 732-734. https://doi.org/10.1177/106002808702100913.

Food and Drug Administration. (2020, March 28). FDA. Accessed May 21, 2020, from FDA, Frequently Asked Question: https://www.fda.gov/media/136784/download

Food and Drug Administration. (2020, Mei 1). Press Announcement. Accessed Mei 21, 2020, from FDA: https:/www.fda.gov/news-events/pressannouncements/coronavirus-covid-19-update-fdaissues-emergency-use-authorization-potential-covid-19treatment.

Gomes, T., Mamdani, M. M., \& Juurlink, D. N. (2009). Macrolide-induced digoxin toxicity: a population-based study. Clinical Pharmacology and Therapeutics, 86(4), 383-386. https://doi.org/10.1038/clpt.2009.127.

Guan, W. J., Ni, Z. Y., Hu, Y., Liang, W. H., Ou, C. Q., He, J. X., Liu, L., Shan, H., Lei, C. L., Hui, D., Du, B., Li, L. J., Zeng, G., Yuen, K. Y., Chen, R. C., Tang, C. L., Wang, T., Chen, P. Y., Xiang, J., Li, S. Y., ... China Medical Treatment Expert Group for Covid-19 (2020). Clinical characteristics of coronavirus disease 2019 in China. The New England Journal of Medicine, 382(18), 1708-1720. https://doi.org/10.1056/NEJMoa2002032.

Harvey C.J., Bateman, N.T., Llyod M.E., Highes, G.R.V., (1995). Influence of rifampicin on hydroxychloroquine. Clinical and Experimental Rheumatology, 13, 536.

Hughes, C. A., Freitas, A., \& Miedzinski, L. J. (2007). Interaction between lopinavir/ritonavir and warfarin. CMAJ: Canadian Medical Association journal = Journal de l'Association Medicale Canadienne, 177(4), 357359. https://doi.org/10.1503/cmaj.061284.

John Hopkins University. (2020, June 24). World Map. Accessed June 24, 2020, from coronavirus.jhu.edu: https://coronavirus.jhu.edu/map.html

The Indonesian Society of Respirology. (2020, April 8). PDPI. Accessed May 21, 2020, from PDPI: https:// perdhaki.org/2020/04/08/tatalaksana-pasien-covid-19oleh-perhimpunan-dokter-paru-indonesia/
Kiser, J. J., Gerber, J. G., Predhomme, J. A., Wolfe, P., Flynn, D. M., \& Hoody, D. W. (2008). Drug/Drug interaction between lopinavir/ritonavir and rosuvastatin in healthy volunteers. Journal of Acquired Immune Deficiency Syndromes (1999), 47(5), 570-578. https:// doi.org/10.1097/QAI.0b013e318160a542.

Khunti, S., Khunti, N., Seidu, S., \& Khunti, K. (2020). Therapeutic uncertainties in people with cardiometabolic diseases and severe acute respiratory syndrome coronavirus 2 (SARS-CoV-2 or COVID-19). Diabetes, obesity \& metabolism, 10.1111/dom.14062. Advance online publication. https://doi.org/10.1111/dom.14062.

Lacy, C. F., Armstrong, L. L., Goldman, M. P., \& Lance, L. L. (2007). Drug Information Handbook (Vol. 20). Hudson, Ohio: Lexi-comp.

Lim, M. L., Min, S. S., Eron, J. J., Bertz, R. J., Robinson, M., Gaedigk, A., \& Kashuba, A. D. (2004). Coadministration of lopinavir/ritonavir and phenytoin results in two-way drug interaction through cytochrome P-450 induction. Journal of acquired immune deficiency syndromes (1999), 36(5), 1034-1040. https://doi. org/10.1097/00126334-200408150-00006.

Ministry of Health, Republic of Indonesia. (2020). COVID-19. Accessed May 21, 2020, from Situs web KemenKes RI: https://covid19.kemkes.go.id/

Mori, T., Aisa, Y., Nakazato, T., Yamazaki, R., Ikeda, Y. and Okamoto, S. (2005), Tacrolimus-azithromycin interaction in a recipient of allogeneic bone marrow transplantation. Transplant International, 18: 757-758. doi:10.1111/j.1432-2277.2005.00135.x

Phillips, E. J., Rachlis, A. R., \& Ito, S. (2003). Digoxin toxicity and ritonavir: a drug interaction mediated through p-glycoprotein?. AIDS (London, England), 17(10), 1577-1578. https://doi.org/10.1097/01. aids.0000072673.21517.d6

Piliero, Peter. (2002). Interaction between ritonavir and statins. The American Journal of Medicine. 112. 510-1. 10.1016/S0002-9343(02)01034-3.

Samarendra, P., Kumari, S., Evans, S. J., Sacchi, T. J., \& Navarro, V. (2001). QT prolongation associated with azithromycin/amiodarone combination. Pacing and clinical electrophysiology : PACE, 24(10), 1572-1574. https://doi.org/10.1046/j.1460-9592.2001.01572.x

Sheikhbahaie, F., Amini, M., Gharipour, M., Aminoroaya, A., \& Taheri, N. (2016). The effect of hydroxychloroquine on glucose control and insulin resistance in the prediabetes condition. Advanced Biomedical Research, 
5, 145 . https://doi.org/10.4103/2277-9175.187401 UCSF. (2019). HIV InSite. Accessed Mei 28, 2020, from UCSF: http://arv.ucsf.edu/insite?page $=$ ar-00$02 \&$ post $=10 \&$ param $=12$.

Wondafrash, D. Z., Desalegn, T. Z., Yimer, E. M., Tsige, A. G., Adamu, B. A., \& Zewdie, K. A. (2020). Potential effect of hydroxychloroquine in diabetes mellitus: A systematic review on preclinical and clinical trial studies. Journal of Diabetes Research, 2020, 5214751. https:// doi.org/10.1155/2020/5214751.
World Health Organization. (2020, April 27). WHO Timeline-COVID-19. Accessed Mei 21, 2020, from WHO.int: https://www.who.int/news-room/detail/2704-2020-who-timeline---covid-19.

Wu, Z., \& McGoogan, J. M. (2020). Characteristics of and important lessons from the coronavirus disease 2019 (COVID-19) Outbreak in China: Summary of a Report of 72314 Cases From the Chinese Center for Disease Control and Prevention. JAMA, 10.1001/ jama.2020.2648. Advance online publication. https:// doi.org/10.1001/jama.2020.2648. 